\title{
ラピッドコミュニケーション
}

\section{急性期における正脂血脳梗塞患者の血清 アポリポ蛋白および血清脂質の検討}

江 隅 英 作 $*$,** 鈴木啓 二林吉田充 男**

\section{I. 目 的}

高脂血症が脳梗塞のリスクファクターであるか 否かには諸説があり，これまでのところ結論が出 ていない。これらの関与を調査する方法として prospective study が重要である.わが国の久山町 における研究では剖検における脳動脈硬化と血清 総コレステロール(以下 TC と略す) 值には明らか な関係は認められなかった1)。また Framingham 研究では脳梗塞の危険因子として高 TC 血症が存 在するのは 55 歳以下の男性のみであった ${ }^{2)}$. 一方 最近の追跡調查では, 高 TC 血症や低 HDL コレ ステロール (以下 HDL-C と略す) 血症と脳梗塞の 間に有意な関係があるという報告がみられる ${ }^{3 \sim 5)}$. 最近リポ蛋白の蛋白部分を構成するアポリポ蛋白 が測定されるようになり，脳梗塞患者における異 常が指摘されており ${ }^{6 \sim 17)}$ 同時に測定した TC，中 性脂肪 (以下 TG と略寸) および HDL-C が正常 対照例と有意差を認めないにもかかわらず，ア ポリポ蛋白のみ有意差を認めたという報告もあ る10,14,16). 一方心゙ットサイドにおいて TC, TG お よび HDL-C がすべて正常值である脳梗塞患者は 多数存在するが，これらの症例においてもアポリ ポ蛋白を測定することにより，脂質代謝異常を証 明し得る可能性がある。そこで今回われわれは発 症急性期における正脂血の脳梗塞患者においてア

* 公立智頭病院内科

** 自治医科大学神経内科

原稿受取日：1991 年 1 月 18 日

採用決定日：1991 年 4 月 10 日
ポリポ蛋白值の異常の有無を血清脂質とともに検 討したので報告する.

\section{II. 対象・方法}

対象は公立智頭病院内科通院および入院中のう ち正脂血脳梗塞患者 42 例である. 慢性期患者は 入院後の食事療法, 運動能力低下，血清脂質およ びアポリポ蛋白の変化をきたすといわれている各 種薬剤投与の影響が考慮されるため, 発症後 2 週 以内の急性期患者に限って検討した. 臨床所見お よび頭部 CT 所見から，皮質枝群 14 例 (男性 9 例, 女性 5 例，平均年齢 $73.5 \pm 9.6$ 歳）と穿通枝群 28 例（男性 15 例，女性 13 例，平均年齢 $67.3 \pm 9.0$ 歳)の 2 群に分け検討した. 正脂血は, 昭和 61 年 度日本動脈硬化学会冬季大会コンセンサス・カ ンファランスの基準值 ${ }^{18)}$ に基づき, 血清 $\mathrm{TC}$ 值 $<220 \mathrm{mg} / \mathrm{d} l$, 血清 $\mathrm{TG}$ 值 $<150 \mathrm{mg} / \mathrm{d} l$ および血. 清 HDL-C 值 $>40 \mathrm{mg} / \mathrm{d} l$ のすべてを満たすものと した。また脳塞栓，糖尿病合併例，脂質に影響を 及ぼす薬剤服用者は対象から除外した．正常対照 例は検診受診者のうち検查成績で異常を認めない 者 27 例 (男性 15 例，女性 12 例，平均年齢 $65.0 \pm$ 6.6 歳)である.

採血は早朝空腹時に行い，直ちに血清分離して 測定した．血清 TC，TG，HDL-C は酵素法で測 定し, LDL コレステロール (以下 LDL-C と略す) は Friedewald 法で計算し，動脈硬化指数 (以下 AI と略す) は (TC-HDL-C)/HDL-C により求め た. 血清アポリポ蛋白 (アポ A-I, アポ B,アポE) は SRID 法により測定し，アポ B とアポ A-I の 
比 (以下アポ B/A-I と略す) および LDL-C とアポ B の比 (以下LDL-C/アポ B と略す) を求めた. 統 計処理には non-paired t test を用いた.

\section{III. 成 績}

脳梗塞群では皮質枝群，穿通枝群とも正常対照 群と比較して, HDL-C (皮質枝群 $50.5 \pm 12.1 \mathrm{mg}$ / $\mathrm{d} l$ ), 穿通枝群 $50.5 \pm 10.6 \mathrm{mg} / \mathrm{d} l$, 対照群 $62.3 \pm$ $18.2 \mathrm{mg} / \mathrm{d} l$ ) およびアポ A-I (皮質枝群 $109.1 \pm 21.3$ $\mathrm{mg} / \mathrm{d} l$ ), 穿通枝群 $115.0 \pm 16.5 \mathrm{mg} / \mathrm{d} l$, 対照群 133.1 $\pm 22.8 \mathrm{mg} / \mathrm{d} l)$ が有意に低值 $(\mathrm{p}<0.01)$ であり, AI （皮質枝群 $2.62 \pm 0.71$, 穿通枝群 $2.62 \pm 0.79$, 対照 群 $2.01 \pm 0.78$ ) およびアポ B/A-I (皮質枝群 $0.80 \pm$ 0.17 , 穿通枝群 $0.76 \pm 0.16$, 対照群 $0.61 \pm 0.16)$ が 有意に高值 $(\mathrm{p}<0.01)$ であった. TC (皮質枝群 $176.5 \pm 20.3 \mathrm{mg} / \mathrm{d} l$, 穿通枝群 $177.0 \pm 24.1 \mathrm{mg} / \mathrm{d} l$, 対照群 $176.8 \pm 28.9 \mathrm{mg} / \mathrm{d} l$ ), TG (皮質枝群 $93.3 \pm$ $25.1 \mathrm{mg} / \mathrm{d} l$, 穿通枝群 $83.6 \pm 24.2 \mathrm{mg} / \mathrm{d} l$, 対 照群 $86.5 \pm 29.9 \mathrm{mg} / \mathrm{d} l$ )，LDL-C (皮質枝群 $107.3 \pm 21.3$ $\mathrm{mg} / \mathrm{d} l$, 穿通枝群 $109.1 \pm 24.2 \mathrm{mg} / \mathrm{d} l$, 対照群 97.1 $\pm 28.4 \mathrm{mg} / \mathrm{d} l$ ), アポ B (皮質枝群 $84.5 \pm 9.7 \mathrm{mg} / \mathrm{d} l$, 穿通枝群 $85.3 \pm 15.3 \mathrm{mg} / \mathrm{d} l$, 対照群 $79.0 \pm 19.1$ $\mathrm{mg} / \mathrm{d} l$ ), アポ $\mathrm{E}$ (皮質枝群 $4.64 \pm 0.79 \mathrm{mg} / \mathrm{d} l$, 穿通
枝群 $4.29 \pm 1.36 \mathrm{mg} / \mathrm{d} l$, 対照群 $4.57 \pm 1.74 \mathrm{mg} / \mathrm{d} l$ ) および LDL-C/アポ B (皮質枝群 $1.27 \pm 0.18$, 穿通 枝群 $1.27 \pm 0.17$, 対照群 $1.22 \pm 0.22)$ のずれも 脳梗塞群と正常対照群間で有意差を認めなかった. また皮質枝群と穿通枝群間ではいずれの検查項目 も有意差を認めなかった (Fig. 1).

\section{IV. 考察}

脳梗塞における血清脂質の検討は, Rössner ら 19) が血清 TC 值が正常な 55 歳以下の脳梗塞患 者に扔いて，正常対照群と比較して HDL-C が有 意に低值であると報告した. Murai ら ${ }^{20)}$ は HDLC の低下のみならず，LDL-C および TC の高值 も脳梗塞群で認められると報告した.さらに彼ら は皮質枝梗塞において，穿通枝梗塞と比較して HDL-C および HDL-C/LDL-C 比が有意に低く， LDL-C が有意に高值であることを指摘してい $ろ^{20)}$. 追跡調查でも脳梗塞と血清脂質に有意な関 係が認められたという報告がある. Oslo 研究では, 血清 TC 值と脳血管病変には正の相関が指摘され, さらに HDL-C/non-HDL-C 比の低值が脳梗塞の 危険因子であった ${ }^{3)}$. MRFIT (Multiple Risk Factor Intervation Trial) では脳梗塞群の死亡率と血

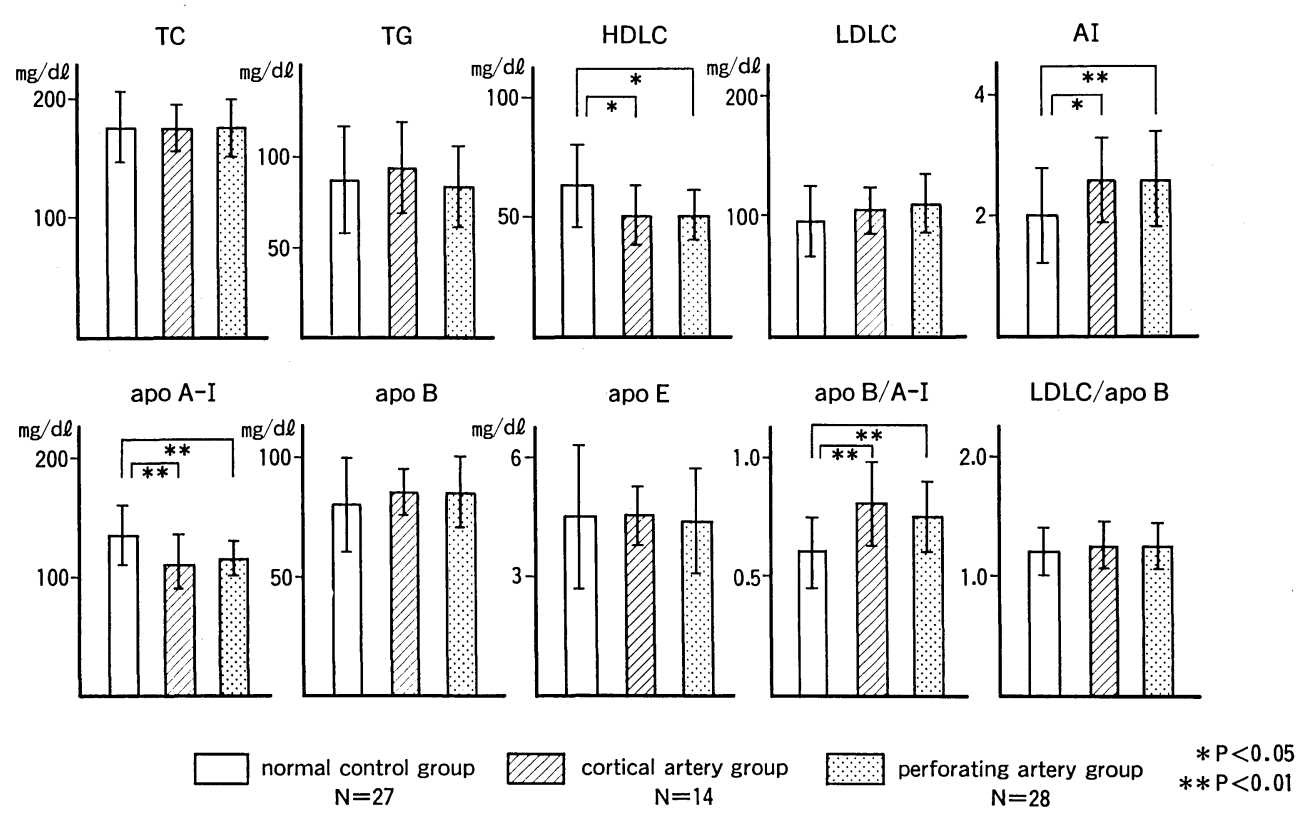

Fig. 1 Serum lipids and apolipoprotein levels of patients with cerebral infarction. 
清 TC 值には正の相関が認められた ${ }^{4)}$. また Kaste ら5) は家族性高 TC 血症患者の追跡研究を行い, 脳梗塞の発症率が一般人と比べ約20倍も高いと報 告した.

一方アポリポ蛋白の検討では, 脳梗塞群におい てアポA-I および A-II が低值であるという報 告6 9,11 15)，アポ B が高值であることを指摘した 報告10,13,14,16)がある.さらに穿通枝梗塞と比較し て皮質枝梗塞でアポ B およびアポ B/A-I の有意な 高值を指摘した報告 ${ }^{13,14)}$ ， HDL-C のみ有意に 低值であった報告17) がある，松田ら ${ }^{10)}$ は，同時 に測定した血清脂質は正常対照例と比較して有意 差がなく,アポ B のみが脳梗塞群において有意に 高值であると報告している。しかしながらこれら の報告はそのほとんどが慢性期の患者を対象とし ており，急性期における検討は稀である．金沢 ら 12) 㴔性期および慢性期 (発症後 2 か月以上) とも正常群と比較してアポ A-I が有意に低值, ア ポEが有意に高值であり，急性期と慢性期の血清 脂質およびアポリポ蛋白を比較していずれの項目 も有意差を認めなかったためアポリポ蛋白值は発 作の時期とは無関係であり，発作時のアポリポ蛋 白を測定すれば発作前の濃度を推測できると指摘 している，脳梗塞急性期は全身的に様々な侵襲が 加わっており，血清脂質やアポ蛋白もその影響を 受けると考えられる。しかしながら慢性期におい ては, 入院後の食事療法および運動能力低下の影 響を受け，さらには多数例で血清脂質およびアポ リポ蛋白代謝に影響を及ぼすといわれている脳 代謝賦活剂, 脳循環改善剂, 降圧剂, 脂質代謝改 善剂等が投与されており，血清脂質およびアポリ ポ蛋白代謝に影響を及ぼす因子が急性期と比較し てより多いと考えられるため, 本研究では対象を 急性期患者とした. 紀田ら ${ }^{14)}$ は入院後の食事療 法による影響を避け入院前の脂質状態を反映する ように入院 2 日以内患者における検討で, 血清脂 質に有意差はないものの，脳梗塞群においてアポ A-I の低值およびアポ B，アポ B/A-I の有意な高 值を認めたと報告している. また発作後 3 時閒以 内の脳梗塞患者で HDL-C, アポA-I およびアポ A-II が有意に低值であったという報告 ${ }^{15)}$ もるる いずれにしても急性期, 慢性期を問わず血清脂質
が正常であってもアポリポ蛋白のみが脂質代謝異 常のマーカーとなる脳梗塞例も存在することが推 察される.

われわれは正脂血者を対象に，脳梗塞のリスク ファクターとして確立されている加齢, 脳卒中家 族歴群および高血圧群において, 正常対照例と比 較してアポ Bのみが有意に高值であることを報告 した ${ }^{21)}$. 本研究では脳梗塞患者で血清脂質が正常 であってもアポリポ蛋白の異常が認められるか否 かをより明確にするため，正脂血例に限って検討 した．昭和61年度日本動脈硬化学会冬季大会コン センサス・カンファランスで定められた血清脂質 の基準值 ${ }^{18)}$ に従い，正脂血例を対象として脳梗 塞患者の血清アポリポ蛋白について検討した報告 は，本研究が初めてである，HDL-C およびアポ A-I が正常対照例と比較して有意に低值を示した 結果は，これまでの報告6 9,11 15) と合致しており， 脳梗塞に打ける脂質代謝異常のマーカーとして有 用と考えられた. 一方アポ B は松田ら ${ }^{10)}$, 紀田 ら ${ }^{14)}$ の報告と異なり，正常対照例との間に有意 差を認めなかった.アポ $\mathrm{B}$ の昇は脳梗塞のリス クファクターである加齢, 脳卒中家族歷を有する 者, 高血圧においては高值となるものの ${ }^{21)}$, 単独 では脳梗塞発症に影響を及ぼしていないと考えら れた。またわれわれの結果では皮質枝梗塞群と穿 通枝梗塞群間でいずれの検查項目も有意差を認め なかった。この理由として，皮質枝梗塞群におい てはアポリポ蛋白の異常より血清脂質の異常が脂 質代謝異常の中核をなしているため，正脂血例に 限った今回の検討では穿通枝群と異なる脂質異常 のパターンが見いだされなかった可能性が示唆さ れたが，この点については今後の詳細な検討が必 要と思われる. 一方, 従来脂質代謝異常の関与が 少ないといわれてきた穿通枝梗塞群においてもア ポリポ蛋白の測定によりその異常が関与している ことが判った.

今回の結果とわれわれの既報告21) から, 脳梗塞 発症における脂質代謝異常のメカニズムとして, まずアポBが上昇して Low Density Lipoprotein (LDL)の変性による動脈硬化が引き起こされ, さ らに High Density Lipoprotein (HDL) の低下を 伴うことにより脳梗塞が発症するという仮説が立 
てられ，アポ B/A-I の高值は脳梗塞発症を予測す るマーカーの一つとして有用である可能性が考え られた。ベッドサイドにおいて，脳梗塞のリスク ファクターとしての脂質代謝異常の有無を論じる 時アポリポ蛋白の測定は重要であり, 脂質代謝異 常が脳梗塞のリスクファクターであるか否かの結 論は, アポリポ蛋白の追跡調査により近い将来解 明されるであろう。

\section{V. 結 論}

正脂血の急性期脳梗塞患者 42 例 (皮質枝群 14 例, 穿通枝群 28 例) の血清アポリポ蛋白および脂 質を測定した. 脳梗塞群では皮質枝群, 穿通枝群 とも正常対照例と比較して HDL コレステロール およびアポ A-I が有意に低值 $(\mathrm{p}<0.01)$ であり， 動脈硬化指数とアポ B/A-I が有意に高值 $(\mathrm{p}<0.01)$ であった. 皮質枝群と穿通枝群間ではいずれの検 查項目も有意差を認めなかった。脳梗塞における 脂質代謝異常のマーカーとして，皮質枝・穿通枝 両群においてアポ A-I および HDL コレステロー ルの測定が有用と考えられた.さらに血清アポリ ポ蛋白を測定することにより, 血清脂質が正常範 囲内の脳梗塞患者でも脂質代謝異常が存在するこ とが判った。

本論文の要旨は第 31 回日本神経学会総会 $(1990$ 年 5 月, 横浜) および平成 2 年度日本動脈硬化学会冬季大会 (1990 年 12 月, 宮崎) で発表した。

\section{文献}

1) Sadoshima, S., Kurozumi, T., Tanaka, K., Ueda, K., Takeshita, M., Hirota, Y., Omae, T., Uzawa, H. and Katsuki, S.: Cerebral and aortic atherosclerosis in Hisayama, Japan. Atherosclerosis, 36: 117-126 (1980).

2) Kannel, W. B., Gordon, T. and Dawber, T. R.: Role of lipids in the development of brain infarction: The Framingham study. Stroke, 5: 679-685 (1974).

3) Holme, I., Enger, S. C., Helgerand, A., Hjermann, I., Leren, P., Lund-Larsen, P. G., Solberg, L. A. and Strong, J. P.: Risk factors and raised atherosclerotic lesions in coronary and cerebral arteries. Statistical analysis from the Oslo study. Arteriosclerosis, 1: 250-256 (1981).
4) Iso, H., Jacobs, D. R., Wentworth, D., Neaton, J. D. and Cohen, J. D.: Serum cholesterol levels and six-year mortality from stroke in 350,977 men screened for the multiple risk factor intervention trial. N. Engl. J. Med., 320: 904-910 (1989).

5) Kaste, M. and Koivisto, P.: Risk of brain infarction in familial hypercholesterolemia. Stroke, 19: 10971100 (1988).

6) 佐藤 敬, 高松 滋, 作田 茂, 水野成徳, 東海林 文一郎, 高松むつ：脳血管障害における血清アポ A-I, A-II 濃度. 動脈硬化, 10: 273-278 (1982).

7) 宮原忠夫, 村井淳志, 亀山正邦 : 脳梗塞とアポ蛋白 A-I, A-II. 動脈硬化, 11: 185-190 (1983).

8) 森 晈祐, 渡辺雄幸, 松田行正, 古見耕一: 脳血管 障害における脂質代謝異常——アホリポ蛋白を中心 飞一一. 脳卒中, 7: 269-274 (1985).

9) 小林陽二, 福生吉裕, 加藤仁志, 中澤良寿, 稲葉治 樹, 渋谷敏道, 羽田和正, 吉井 博, 赫 榇郎, 金 川卓郎：老年慢性期脳梗塞例飞おける血清脂質おょ び血液凝固線溶関連因子についての検討. 日老医誌, 22: 340-345 (1985).

10) 松田 実, 藤本直規, 龟山正邦, 宮原忠夫, 村井淳 志：脳梗塞患者のリポ蛋白代謝異常—アポ蛋白値 を中心に一。. 動脈硬化, 13: 561-566 (1985).

11) 福沢恒利, 鳥浜慶嗣, 長島 勉, 山本 実, 及川孝 光, 山内喜夫, 広瀬信義, 重松 洋, 秦 臀哉, 岸 久博, 荒木五郎: 脳血管障害における血清リポ蛋白 とアポ蛋白の研究 (I). 動脈硬化, 13: 567-577 (1985).

12）金沢武道, 井沢和弘, 金子宏彦, 小野寺庚午, 目時 弘文, 大池弥三郎：脳卒中の臨床経過ならびに病態 におけるアポ蛋白質の意義. Ther. Res., 3: 358-365 (1985).

13）福沢恒利: 脳血管障害におけるリポ蛋白とアポ蛋白 の研究—LDL 組成と LDL サイズの意義——. 脳卒中, 9: 354-370 (1987).

14）紀田康雄, 澤田 徹, 栗山良紘, 成富博章, 山口武 典, 原納優, 柏木厚典, 小島秀人, 繁田幸男: 脳梗 塞患者における主幹動脈病変の有無と脂質代謝異常. 日内会誌, 77: 788-792 (1988).

15) Kostner, G. M., Marth, E., Pfeiffer, K. P. and Wege, H.: Apolipoproteins AI, AII and HDL phospholipids but not apo-B are risk indicators for occlusive cerebrovascular disease. Eur. Neurol., 25: 346-354 (1986).

16) Matsuda, M., Miyahara, T., Murai, A., Fujimoto, N. and Kameyama, M.: Lipoprotein abnormalities in survivors of cerebral infarction with a special reference to apolipoproteins and triglyceride-rich lipoproteins. Atherosclerosis, 68: 131-136 (1987).

17) Adams, R. J., Carroll, R. M., Nichols, F. T., McNair, N., Feldman, D. S., Feldman, E. B. and Thompson, W. O.: Plasma lipoproteins in cortical versus lacunar infarction. Stroke, 20: $448-452$ (1989). 
18) 昭和 61 年度日本動脈硬化学会 冬季大会コンセンサ ス・カンファランス「コレステロール・トリグリセ ライド」(1987).

19) Rössner, S., Kjellin, K. G., Mettinger, K. L. and Siden, A. : Normal serum-cholesterol but low H. D. L.-cholesterol concentration in young patients with ischaemic cerebrovascular disease. Lancet, i: 577579 (1978).
20) Murai, A., Tanaka, T., Miyahara, T. and Kameyama, M.: Lipoprotein abnormalities in the pathogenesis of cerebral infarction and transient ischemic attack. Stroke, 12: 167-172 (1981).

21）江隅英作，鈴木啓二，吉田充男，櫻林郁之介：脳梗 塞のリスクファクターにおける血清アポリポ蛋白お よび脂質の検討. 動脈硬化，18: 111-116 (1990).

\title{
Summary
}

\section{Apolipoprotein Abnormalities in Normolipidemic Acute Cerebral Infarction Subjects}

\author{
Eisaku Esumi ${ }^{*}, * *$ Keiji SuzuKI** and Mitsuo YoshIDA** \\ *Department of Internal Medicine, Chizu Municipal Hospital \\ ** Department of Neurology, Jichi Medical School
}

Hyperlipidemia has not been established as a risk factor of cerebral infarction. Recently, apolipoprotein abnormalities in cases of cerebral infarction have been reported. At the same time, there have been many patients with normolipidemic cerebral infarction. We examined serum the apolipoprotein (apo A-I, B, E) and lipid (Total cholesterol, TC; Triglyceride, TG; HDL-cholesterol; HDL-C) levels in patients with normolipidemic acute cerebral infarction. The subjects were 14 patients with cerebral infarction in the are a of the cortical arteries (CIC) (9 males, 5 females, mean age: $73.5 \pm 9.6$ years old), 28 patients with cerebral infarction in the area of the perforating arteries (CIP) (15 males, 13 females, mean age: $67.3 \pm 9.0$ years old) and 27 normal healthy controls (NC)
(15 males, 12 females, mean age: $65.0 \pm 6.6$ years old). The definition of normolipidemia applies the criteria of the Consensus Conference of Japan Atherosclerosis Society in 1987. In CIC and CIP subjects, the levels of HDL-C and apo A-I were significantly lower than the levels of $\mathrm{NC}(\mathrm{p}<0.01)$, and the atherogenic index (TC-HDL-C/HDL-C), and the apo B/A-I ratio was significantly higher than that of $\mathrm{NC}(\mathrm{p}<0.01)$. There were no significant differences between CIC and CIP in the levels of lipids and other apolipoproteins. These results suggest that apo A-I and HDL-C are useful indicators of lipid metabolism abnormalities in cases of cerebral infarction.

Key words: cerebral infarction, lipid metabolism, apolipoprotein, normolipidemia. 